\title{
Jökulhlaups in Iceland: prediction, characteristics and simulation
}

\author{
HELGI BJÖRNSSON \\ Science Institute, University of Iceland, Dunhaga 5, 107 Reykjavik, Iceland
}

\begin{abstract}
Jökulhlaups drain regularly from six subglacial geothermal areas in Iceland. From Grímsvötn in Vatnajökull, jökulhlaups have occurred at 4 to 6 yearly intervals since the $1940 \mathrm{~s}$ with peak discharges of 600 to $10000 \mathrm{~m}^{3} \mathrm{~s}^{-1}$, durations of 2 to 3 weeks and total volumes of 0.5 to $3.0 \mathrm{~km}^{3}$. Prior to that about one jökulhlaup occurred per decade, with an estimated discharge of $5 \mathrm{~km}^{3}$ of water and a peak discharge of approximately $30000 \mathrm{~m}^{3} \mathrm{~s}^{-1}$. Clarke's (1982) modification of Nye's (1976) general model of discharge of jökulhlaups gives, in many respects, satisfactory simulations for jökulhlaups from Grímsvötn, the best fit being obtained for Manning roughness coefficients $\mathrm{n}=0.08$ to $0.09 \mathrm{~m}^{-1 / 3} \mathrm{~s}$ and a constant lake temperature of $0.2^{\circ} \mathrm{C}$ (which is the present lake temperature). The rapid ascent of the exceptional jökulhlaup of 1938, which accompanied a volcanic eruption, can only be simulated by a lake temperature of the order of $4^{\circ} \mathrm{C}$.

Jökulhlaups originating at geothermal areas beneath ice cauldrons located 10 to $15 \mathrm{~km}$ northwest of Grímsvötn have a peak discharge of 200 to $1500 \mathrm{~m}^{3} \mathrm{~s}^{-1}$ in 1 to 3 days, with total volume of 50 to $350 \times 10^{6} \mathrm{~m}^{3}$, and they recede slowly in 1 to 2 weeks. The form of the hydrograph has reversed asymmetry to that of a typical Grímsvötn hydrograph. The reservoir water temperature must be well above the melting point $\left(10\right.$ to $\left.20^{\circ} \mathrm{C}\right)$ and the flowing water seems not to be confined to a tunnel but to spread out beneath the glacier and later gradually to collect back to conduits.

Since the time of the settlement of Iceland ( $870 \mathrm{AD})$, at least 80 subglacial volcanic eruptions have been reported, many of them causing tremendous jökulhlaups with dramatic impact on inhabited areas and landforms. The peak discharges of the largest floods (from Katla) have been estimated at the order of 100000 to $300000 \mathrm{~m}^{3} \mathrm{~s}^{-1}$, with durations of 3 to 5 days and total volume of the order of $1 \mathrm{~km}^{3}$. It is now apparent that the potentially largest and most catastrophic jökulhlaups may be caused by eruptions in the voluminous ice-filled calderas in northern Vatnajökull (of Bárdharbunga and Kverkfjöll). They may be the source of prehistoric jökulhlaups, with estimated peak discharge of $400000 \mathrm{~m}^{3} \mathrm{~s}^{-1}$.

At present, jökulhlaups originate from some 15 marginal ice-dammed lakes in Iceland. Typical values for peak discharges are 1000 to $3000 \mathrm{~m}^{3} \mathrm{~s}^{-1}$, with durations of 2 to 5 days and total volumes of $2000 \times 10^{6} \mathrm{~m}^{3}$. Hydrographs for jökulhlaups from marginal lakes have a shape similar to those of the typical Grímsvötn jökulhlaup. Simulations describe reasonably well the ascending phase of the hydrographs assuming a constant lake temperature of about $1^{\circ} \mathrm{C}$; but they fail to describe the recession. Some floods from marginal lakes, however, have reached their peaks exceptionally rapidly, in a single day. Such rapid ascent can be simulated by assuming drainage of lake water at 4 to $8^{\circ} \mathrm{C}$.

An empirical power-law relationship is obtained between peak discharge, $Q_{\max }$, and total volume, $V_{\mathrm{t}_{2}}$ of the jökulhlaups from Grímsvötn: $Q_{\max }=\mathrm{K} V_{\mathrm{t}}^{\mathrm{b}}$, where $Q_{\max }$ is measured in $\mathrm{m}^{3} \mathrm{~s}^{-1}, V_{\mathrm{t}}$ in $10^{6} \mathrm{~m}^{3}, \mathrm{~K}=4.15 \times 10^{-3} \mathrm{~s}^{-1} \mathrm{~m}^{-2.52}$ and $\mathrm{b}=1.84$. In general, the jökulhlaups (excepting those caused by eruptions) occur when the lake has risen to a critical level, but before a lake level required for simple flotation of the ice dam is reached. The difference between the hydrostatic water pressure maintained by the lake and the ice overburden pressure of the ice dam is of the order 2 to 6 bar.
\end{abstract}

\section{INTRODUCTION}

Glacier-related floods, jökulhlaups, are frequent in Iceland. They can be traced to (1) subglacial lakes at geothermal areas, (2) meltwater drained during volcanic eruptions and (3) marginal ice-dammed lakes. Jökulhlaups are major events; they may profoundly affect the landscape, and they threaten human life and property. In Iceland, jökulhlaups have caused the loss of lives, ruined farms and cultivated land, and devastated large vegetated areas. They threaten roads, bridges and hydroelectric power plants on glacier-fed rivers. Their effects on the landscape are seen in the erosion of large canyons and in the transport and deposition of sediments over outwash 
plains. Knowledge of the sources and behaviour of jökulhlaups is essential for advance warnings, preventive measures and civil defence in Iceland.

In Iceland, records of the occurrence of jökulhlaups going back centuries are recorded in annals and in various medieval documents, the oldest reference being to an event which occurred around $1330 \mathrm{AD}$ (Thorarinsson, 1974). Since the 1930s, jökulhlaups have been monitored, and data are available on their frequency, duration and impact (Thorarinsson, 1939, 1953, 1965, 1974; Rist, 1955, 1967, 1973, 1976a, b, 1981, 1984; Kristinsson and others, 1986; Björnsson, 1974, 1975, 1988). Hydrographic measurements have been taken and peak discharges estimated. The sources of the jökulhlaups have been pinpointed and data obtained on the variation in lake levels and the elevation of ice dams. Such data have been used for predicting the timing of jökulhlaups from Grímsvötn. This lake is a source of frequent, large and often catastrophic floods. Björnsson (1974, 1975, 1988) has discussed how the subglacial lakes are formed and the conditions which obtain at the beginning of jökulhlaups.

Attempts have been made to simulate theoretically several Icelandic jökulhlaups (Nye, 1976; Spring and Hutter, 1981; Clarke, 1982). After developing his general theory, Nye (1976) simulated, as a case study, the hydrograph of the 1972 jökulhlaup from Grimsvötn. Spring and Hutter (1981) made an attempt to describe the same hydrograph by numerical modelling. Further, Clarke (1982) developed models which are relevant to this problem.

During the last few years, the geometry of the subglacial sources of jökulhlaups and their drainage channels has been mapped in detail using radio-echo soundings (Björnsson, 1988). This has provided data on the subglacial water pressure maintained by the lakes and the ice overburden pressure at the ice dams, which can be used for studying conditions at the onset of jökulhlaups. Further, data on the lake volumes and the volume distribution with elevation and the geometry of the ice dams have been obtained (Björnsson, 1988, p. 77) and readings taken of the water temperature in Grímsvötn (unpublished data of the Science Institute). Hence, work on theoretical prediction of the hydrographs and the total volumes of the jökulhlaups, which was put aside in the early 1980s due to lack of boundary conditions in the numerical computations (i.e. unpublished work by $\mathrm{H}$. Björnsson and T. Jóhannesson), can be resumed.

The present paper gives an overview of jökulhlaups in Iceland and, by the use of selected data, seeks to analyze the processes that cause the triggering of jökulhlaups and their drainage.

\section{SOURGES OF JÖKULHLAUPS IN ICELAND}

\section{Subglacial lakes}

Jökulhlaups occur regularly from subglacial lakes in the neovolcanic zone (Thorarinsson, 1953; Björnsson, 1988). Geothermal heat melts ice at the glacier bed continuously, and the meltwater is trapped in a lake at the bed. The melting creates a depression in the glacier surface,

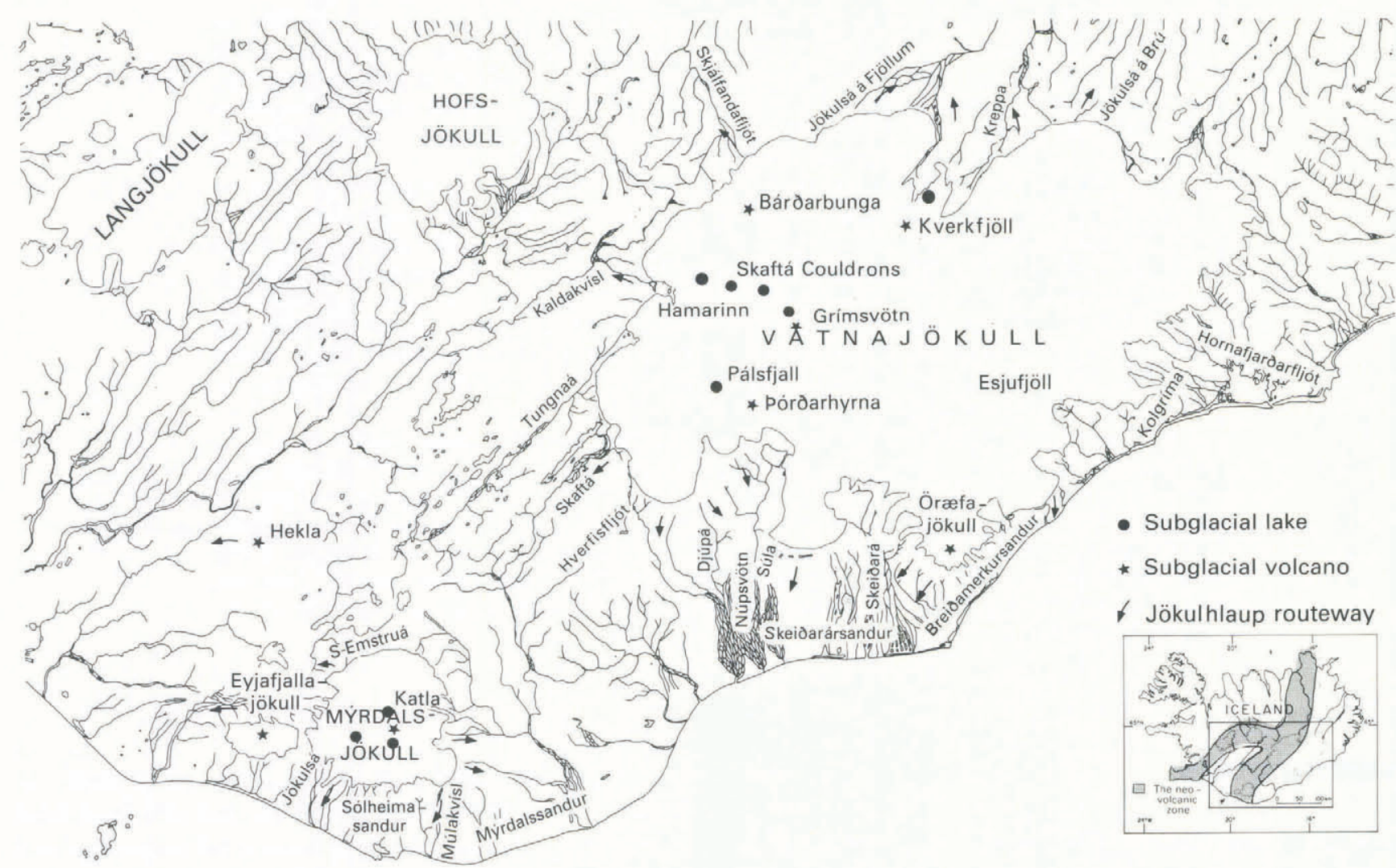

Fig. 1. Location of subglacial lakes at geothermal areas and sites of subglacial volcanic eruptions in Iceland, and rivers affected by jökulhlaups in historical times. 
Table 1. Selected subglacial lakes in Iceland and typical values for their jökulhlaups (all elevations are given in $m$ above sea level)

Grimsvötn Grimsvötn $\begin{gathered}\text { East Skaftá } \\ \text { cauldron }\end{gathered} \quad$ Katla

before $1940 \quad$ after $1940 \quad$ since $1955 \quad 1955$

Maximum lake area $\left(\mathrm{km}^{2}\right)$

Period (a)

Duration (week)

Peak discharge $\left(10^{3} \mathrm{~m}^{3} \mathrm{~s}^{-1}\right)$

Volume $\left(10^{9} \mathrm{~m}^{3}\right)$

Initial lake-level elevation, $z_{\text {iw }}$

Final lake elevation, $z_{\mathrm{fw}}$

Mean ice-shelf thickness (m)

Length of drainage tunnel $(\mathrm{km}), l_{\mathrm{t}}$

Glacier-surface elevation at seal, $z_{\mathrm{ss}}$

Glacier-bed elevation at seal, $z_{\mathrm{sb}}$

Distance from lake to seal $(\mathrm{km}), l_{\mathrm{s}}$

Elevation of tunnel outlet, $z_{\mathrm{t}}$

Lake geometry

Rivers (Fig. 1)

Reference (see below)

30
$7-10$
$1-2$
$30-40$
$4-5$
$1440-1450$
$1280-1300$
150
50
$1520-1540$
1050
$2-2.5$
100
Fig. 2
Skeidará, Gigd
(a)

17-30

2-3

$2-10$

$1-3$

$1420-1450$

$1300-1350$

$150-250$

50

1530-1540

1050

3.5

100

Fig. 2
a, Súla

(a), (b), (c)
7

$2-3$

0.7

1

0.02

1270

1190

500

15

1280

900

0

180

\#

Skaftá

(b)
Múlakvísl

(d)
\# a bowl-shaped cupola
(a) Thorarinsson, 1974
(b) Rist, 1955, 1973, 1976a, b, 1984; Kristinsson and others, 1986
(c) Björnsson, 1988
(d) Rist, 1967

and the lake is sealed by the high ice overburden pressure on a rim around the depression. However, ice and water flow towards the centre of the depression and meltwater accumulates in the lake until the seal is broken, water rushes out, and a jökulhlaup is initiated. Six subglacial lakes are known beneath Vatnajökull and at least three beneath Mýrdalsjökull (Fig. 1). Table 1 gives some values on the geometry of selected lakes and typical values for the jökulhlaups which originate from them. Figure 2 gives hypsometric data for Grímsvötn.

Jökulhlaups have been reported from Grímsvötn for the last six centuries. In the most violent jökulhlaups, the entire outwash plain, Skeidharársandur, has been flooded. During the last century and up to the 1940s, jökulhlaups from Grímsvötn were larger than they have been during the last 50 years. Since the 1960s, these jökulhlaups have become smaller as the volume of the lake has diminished. The area of the lake has become smaller and the floating ice shelf thicker due to reduced subglacial melting (Björnsson, 1988).

Since 1955, twenty jökulhlaups have originated in two geothermal areas beneath the Skaftá ice cauldrons (Fig. 1), located 10 to $15 \mathrm{~km}$ to the northwest of Grimsvötn (Björnsson, 1977, 1988). They drain to the river Skaftá. Since 1980, jökulhlaups have occurred in the river

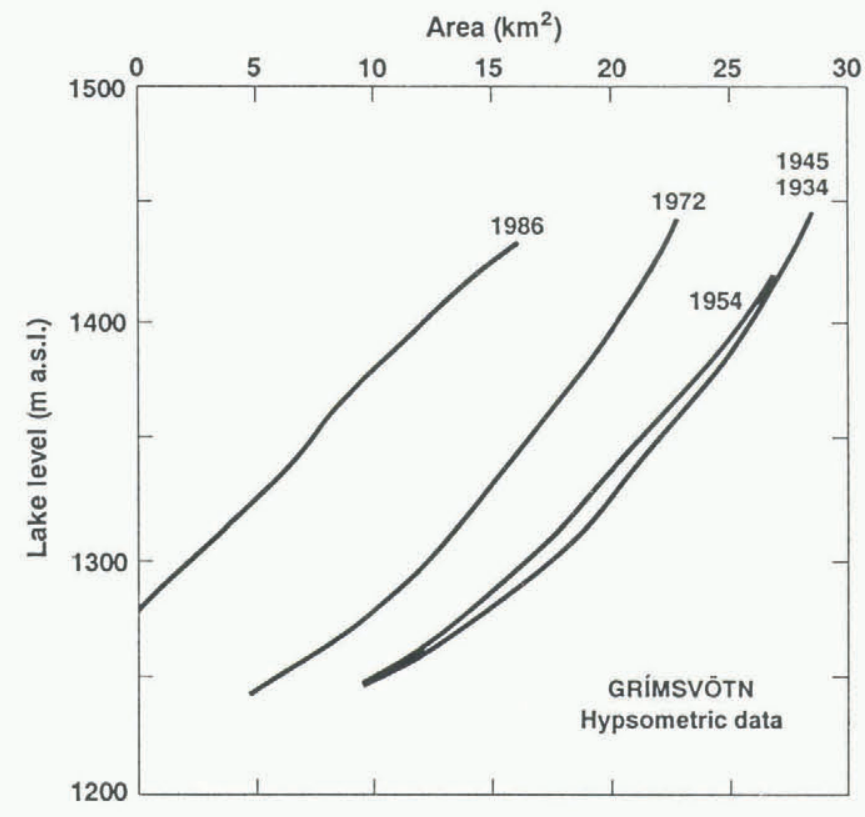

Fig. 2. Area distribution with elevation for Grimsvötn. Based on information on the thickness of the ice cover and the surface topography (Björnsson, 1988; Gudhmundsson, 1989; unpublished work by M. T. Gudhmundsson and $H$. Björnsson). 
Kaldakvísl from a cauldron west of the Skaftá cauldrons. Every year jökulhlaups occur from a small lake $\left(0.1 \mathrm{~km}^{2}\right)$ in the Kverkfjöll geothermal area in northern Vatnajökull. A small subglacial lake is found in the Pálsfjall area $20 \mathrm{~km}$ southwest of Grímsvötn, but no observations have been obtained of its jökulhlaups. From Mýrdalsjökull, jökulhlaups from small subglacial lakes drain frequently towards the southeast into the river Múlakvísl (e.g. in 1955) and north into the south Emstruá river (Fig. 1).

\section{Volcanically triggered floods}

About $60 \%$ of glaciers in Iceland are underlain by the active neovolcanic zone, and since $870 \mathrm{AD}$ more than 80 subglacial volcanic eruptions have been reported (Fig. 1). For Vatnajökull, 63 certain and 13 questionable volcanic events have been reported in historical times. New knowledge on the topography of the surface and the bottom of Vatnajökull makes it possible to trace jökulhlaups in various rivers to their possible volcanic sources (Björnsson and Einarsson, 1991). Volcanic activity in historical times has been associated mainly with the Grímsvötn and Bárdharbunga systems. In Grímsvötn, the most active volcanic centre of Vatnajökull, some eruptions may have been triggered by the pressure release above the volcano subsequent to the lake level falling about $100 \mathrm{~m}$ in a jökulhlaup.

The rivers Skeidhará and Súla have the most frequent eruption-related jökulhlaups. They receive meltwater from the Grímsvötn caldera and the area to the southwest of it, including Thórdharhyrna. Núpsvötn may receive meltwater from eruptions on the southern flanks of Thórdharhyrna. Djúpá drains meltwater from the western slopes of Thórdharhyrna. Jökulhlaups in Hverfisfljót may originate from eruptions in the Pálsfjall area. Skaftá drains the area west of Grímsvötn. Jökulhlaups in Kaldakvísl must originate in the Bárdharbunga or the Hamarinn volcanic systems. The only possible source for volcanic jökulhlaups in Skjálfandafljót is the northern part of the Bárdharbunga system. Jökulsá á Fjöllum may receive meltwater from activity in all the volcanic systems in northern Vatnajökull between Bárdharbunga and Kverkfjöll towards the northern part of the Grímsvötn system. The potentially largest and most catastrophic jökulhlaups may be caused by eruptions in the voluminous, ice-filled calderas of Bárdharbunga and Kverkfjöll (Björnsson, 1988; Björnsson and Einarsson, 1991). They may be the source of prehistoric jökulhlaups in Jökulsá á Fjöllum, with estimated peak discharges of up to $400000 \mathrm{~m}^{3} \mathrm{~s}^{-1}$ (Tómasson, 1973, 1990) that eroded the deep canyons in Jökulsá á Fjöllum. Kreppa and Jökulsá á Brú may receive meltwater from volcanic activity on the eastern flank of a ridge that strikes south from Kverkfjöll.

Seventeen volcanic eruptions have been traced to Katla in Mýrdalsjökull, all causing tremendous jökulhlaups with dramatic impact on inhabited areas and landforms. The peak discharge of the floods of duration 3 to 5 days has been estimated at 100000 to $300000 \mathrm{~m}^{3} \mathrm{~s}^{-1}$ and the total volume of the order of $1 \mathrm{~km}^{3}$ (Thorarinsson, 1957, 1975; Maizels, 1989, 1991). The flood consists of a hyperconcentrated fluid-sediment mixture (Jónsson, 1982; Maizels, 1989). Mýrdalssandur, and the adjacent Sólheimasandur, and Skógasandur have to a large extent

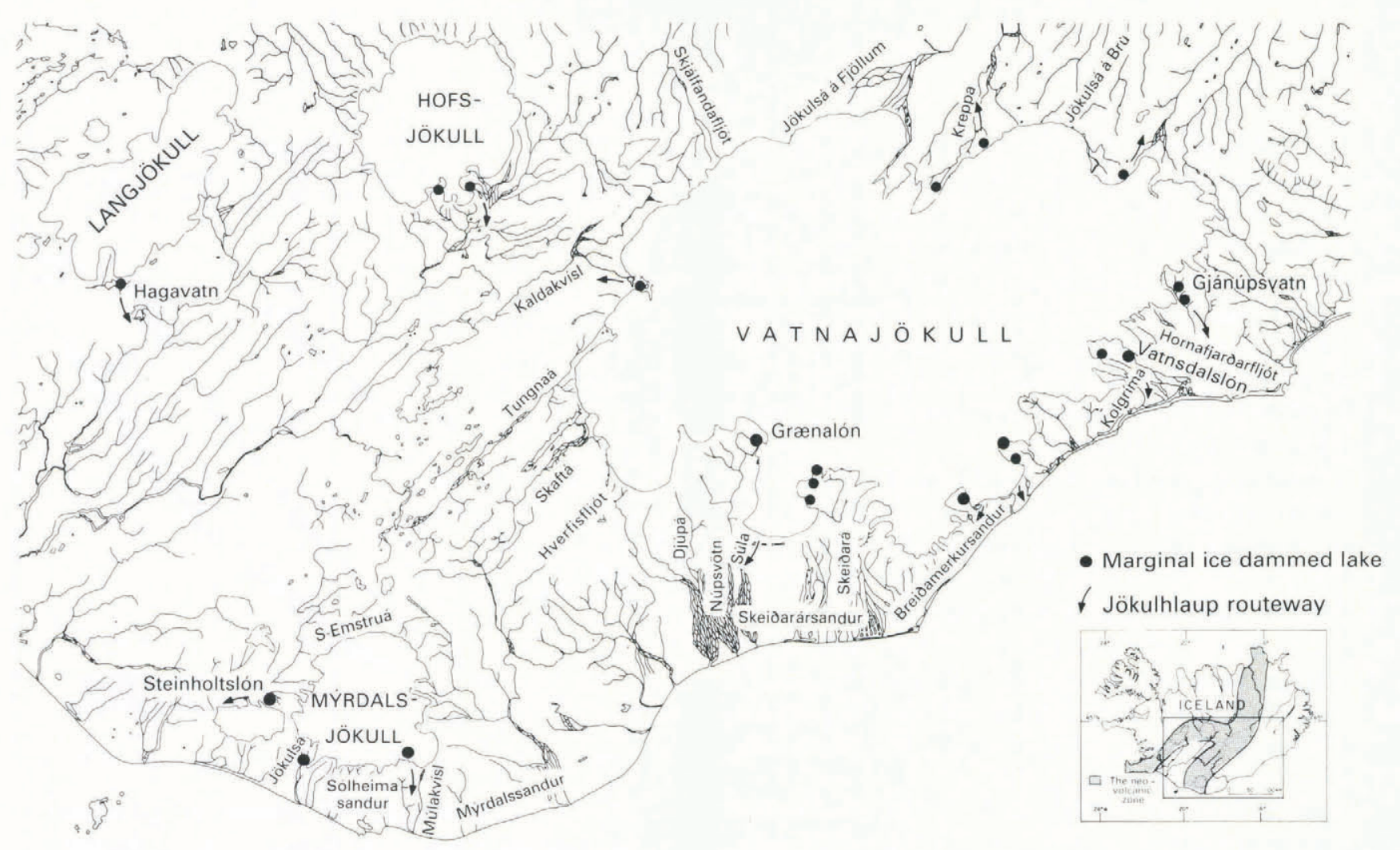

Fig. 3. Location of ice-dammed marginal lakes in Iceland and rivers affected by jökulhlaups from these lakes during the 20 th century. 
been accumulated in floods caused by volcanic eruptions of the ice-covered volcano Katla in Mýrdalsjökull (Fig. 1). During the last eruption in 1918, a jökulhlaup moved the coastline seawards by $200 \mathrm{~m}$, and this coastline now lies 2.2 to $2.5 \mathrm{~km}$ further south than it did in 1660 .

Eruptions in Öræfajökull in the years 1362 and 1727 and in Eyjafjallajökull in 1821-23 were all accompanied by catastrophic jökulhlaups (Thorarinsson, 1958, 1975). Small jökulhlaups due to melting of glaciers on the volcano Hekla took place during the eruptions of 1947 (Kjartansson, 1951), 1970, and 1981 (P. Einarsson, personal communication, 1990).

Monitoring of seismic activity gives warnings of volcanic activity, and maps of bedrock topography and glacier surface can be used to predict hazard zones due to jökulhlaups (Björnsson and Einarsson, 1991).

\section{Marginal lakes}

At present, jökulhlaups originate from some 15 marginal ice-dammed lakes in Iceland (Fig. 3; Thorarinsson, 1939; Björnsson, 1976). The thinning of glaciers, which began around the turn of the last century, initiated jökulhlaups from marginal lakes which during the 19th century had drained continuously over a col (e.g. Grænalón and Vatnsdalslón). These floods caused much damage to farms and vegetated land (e.g. Vatnsdalsón and Hagavatn). They were unexpected, and drained lakes which were filled to their maximum capacity. During the later glacier recession, jökulhlaups have become more frequent (occurring once, even twice, a year), although gradually becoming smaller in volume due to the thinning of the ice dams. This trend has been manifested in successive lowering of shorelines in marginal lakes. Also, the number of ice-dammed lakes generating jökulhlaups has been greatly reduced, and the subsequent damage largely limited to roads and bridges. In a few instances, this trend has been interrupted by the thickening of ice dams during surges and temporary formation of new ice-dammed lakes (e.g. Hamarslón after surges of the outlet Köldukvíslarjökull in northwest Vatnajökull, draining to Kaldakvísl (Fig. 3)). The advance of some steep and active glacier outlets during a cold spell in the 1970 s has dammed ravines at the glacier margin, which have dumped small jökulhlaups. This has occurred, for instance, at Sólheimajökull, a south-facing outlet of Mýrdalsjökull.

In general, the impact of the present-day jökulhlaups from ice-dammed marginal lakes is small compared with those which eroded several large canyons in Iceland at the end of the last glacial period (Tómasson, 1973, 1990).

Table 2 gives some values on the geometry of three marginal ice-dammed lakes and typical values for the jökulhlaups which originate from them. The two columns for the lakes Grænalón and Vatnsdalslón show changes in the size of jökulhlaups in this century. Hypsometric data for Grænalón were published by Björnsson and Pálsson (1989).

Table 2. Selected marginal lakes in Iceland and typical values for their jökulhlaups (all elevations are given in $m$ above sea level)
Granalón
Vatnsdalslón
Gjánúpsvatn

1898-c. 1940 after 1950

1898

1974

1951

Maximum lake area $\left(\mathrm{km}^{2}\right)$
Period (a)
Duration (week)
Peak discharge $\left(10^{3} \mathrm{~m}^{3} \mathrm{~s}^{-1}\right)$
Volume $\left(10^{9} \mathrm{~m}^{3}\right)$
Initial lake-level elevation, $z_{\mathrm{iw}}$
Final lake elevation, $z_{\mathrm{fw}}$
Length of drainage tunnel (km),
Glacier-surface elevation at seal, $z$
Glacier-bed elevation at seal, $z_{\mathrm{sb}}$
Distance from lake to seal (km), $l_{\mathrm{s}}$
Elevation of tunnel outlet, $z_{\mathrm{t}}$
Lake geometry
Rivers (Fig. 3 )
References (see below)

(a) Thorarinsson, 1939
(b) Rist, 1973, 1976b, 1981, 1984
(c) Arnborg, 1955
(d) Björnsson and Pálsson, 1989

22.5

1

4-5

1.5-2

640

450

20

700

c. 580

2.5

90

(d)

(a)
16

0.5-1

1

1.5-2

$0.2-0.5$

590

560

20

c. 620

?

0

90

Súla

$\begin{array}{cc} & 1.9 \\ 1 / 7 & 0.5-1 \\ 3 & 0.6 \\ 120 \times 10^{-3} & 0.7 \\ 464 & 37 \times 10^{-3} \\ 350 & 350 \\ 7 & 7 \\ 370 & 370 \\ 230 & 230 \\ 1 & 1 \\ 90 & 100\end{array}$

1

$0.5-1$

0.37

$20 \times 10^{-3}$

227

200

4.5

60

Hornafjardarfljót

(c)
(a) Thorarinsson, 1939
(b) Rist, 1973, 1976b, 1981, 1984
(d) Björnsson and Pálsson, 1989

(b)

(a) (b) 


\section{THE DISGHARGE OF JÖKULHLAUPS FROM VARIOUS ICE-DAMMED LAKES}

During the last 60 years, discharges of many jökulhlaups have been estimated. Early estimates were based on eyewitness accounts of the width, depth and slope of the flood and, in some cases, the surface velocity. The Manning formula was used to compute the discharge. The absolute accuracy of the computed discharge is about $20 \%$, but relative accuracy is better, and the forms of the hydrographs are considered quite reliable (Thorarinsson, 1939, 1953, 1965, 1974; Rist, 1955, 1973, 1976a, b; Björnsson, 1988). Some of the earlier hydrographs of jökulhlaups from Grímsvötn have now been scaled down using new estimates of the total water volume drained out of this lake (unpublished work by M. T. Gudhmundsson and $\mathrm{H}$. Björnsson), assuming that the original form of the hydrographs was correct. For the last two decades some jökulhlaups (e.g. in Skaftá and from some marginal lakes) have been recorded with limnigraphs, and after 1976 the hydrographs of the Grímsvötn jökulhlaups have been constructed from measurements from the bridges on Skeidharársandur (Rist, 1976a; Kristinsson and others, 1986).

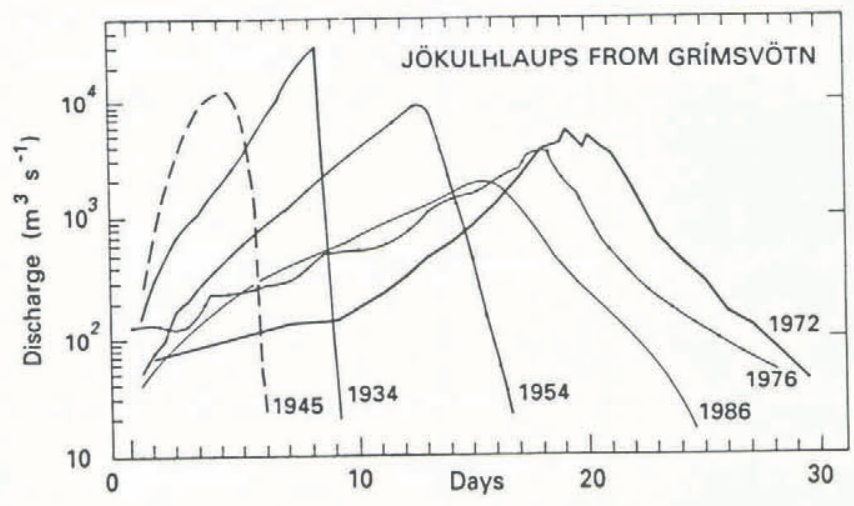

Fig. 4. Typical hydrographs of jökulhlaups from Grimsvötn in Vatnajökull (Thorarinsson, 1974; Rist, 1955, 1973, 1984; Kristinsson and others, 1986). The jökulhlaups up to 1986 are scaled down according to new estimates of the total volume (unpublished work by $M . T$. Gudhmundsson and H. Björnsson).

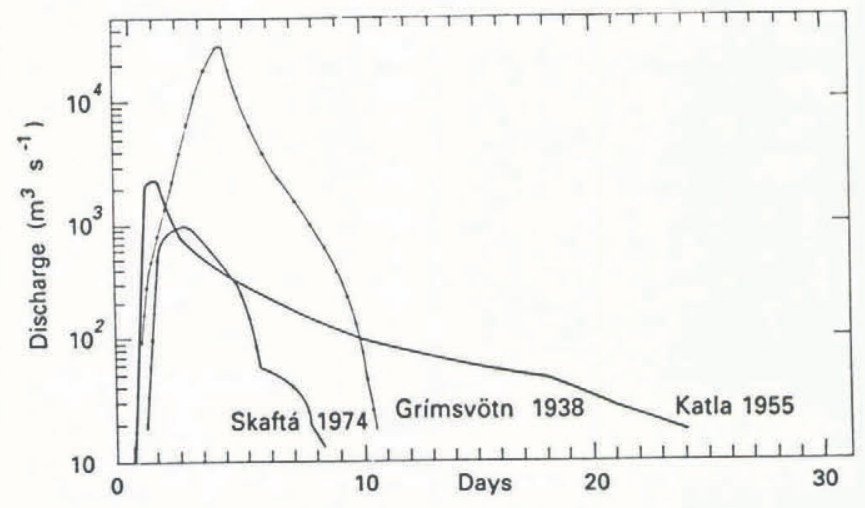

Fig. 5. Typical hydrographs from the subglacial icedammed lake beneath Skaftá cauldron, the jökulhlaup from Grimsvötn in 1938 and the Katla area in 1955 (Thorarinsson, 1974; Rist, 1967, 1976b).
Hydrographs for jökulhlaups from three subglacial lakes are shown in Figures 4 and 5. The typical hydrographs of jökulhlaups from Grímsvötn rise approximately exponentially, but, having reached the peak, the discharge falls more rapidly (Fig. 4). The duration of the larger floods tends to be shorter than that of the smaller ones. In 1934 and 1945, the floods reached their peak in one week and subsided in two days. The smaller jökulhlaups peak in 2 to 3 weeks, and most of them terminate in about one week. In general, the slope of the rising limb has gradually become lower. In all cases, the jökulhlaups end before Grímsvötn is empty (Björnsson, 1974, 1988).

The typical hydrograph for jökulhlaups from the eastern Skaftá cauldron (Fig. 5) is quite different from that for Grímsvötn. It rises rapidly, in 2 to 3 days, to a maximum of 1000 to $1500 \mathrm{~m}^{3} \mathrm{~s}^{-1}$ and recedes slowly in 1 to 2 weeks. Its form has, in these respects, a reversed asymmetry of the typical Grímsvötn hydrograph.

The hydrograph of the jökulhlaup from the Katla area in Mýrdalsjökull in 1955 represents the third type of jökulhlaup, with an extremely rapid rise (Fig. 5). This jökulhlaup reached a maximum discharge of $2500 \mathrm{~m}^{3} \mathrm{~s}^{-1}$ in $20 \mathrm{~h}$ and subsided slowly over a period of about three weeks (Rist, 1967). Thorarinsson (1957) suggested that this hydrograph represented the form of the large jökulhlaups caused by volcanic eruptions in Katla, which reach peak discharge on the order of 100000 to $300000 \mathrm{~m}^{3} \mathrm{~s}^{-1}$ in one day. In such catastrophic jökulhlaups, however, the floods break up the ice dam and flow over it, while in the jökulhlaup of 1955 the lake drained through subglacial tunnels that were melted and expanded gradually, although the burst was probably triggered by a small eruption.

In one exceptional case, a jökulhlaup from Grímsvötn had a steep ascent and a slow recession like the jökulhlaups from the eastern Skaftá cauldron and the Katla area. This was in 1938, when a peak of about $30000 \mathrm{~m}^{3} \mathrm{~s}^{-1}$ was reached in four days and the flood receded in one week (Fig. 5).

Figure 6 shows selected hydrographs for jökulhlaups from marginal lakes (Fig. 3). All the hydrographs have a shape similar to the typical Grímsvötn jökulhlaup. Some

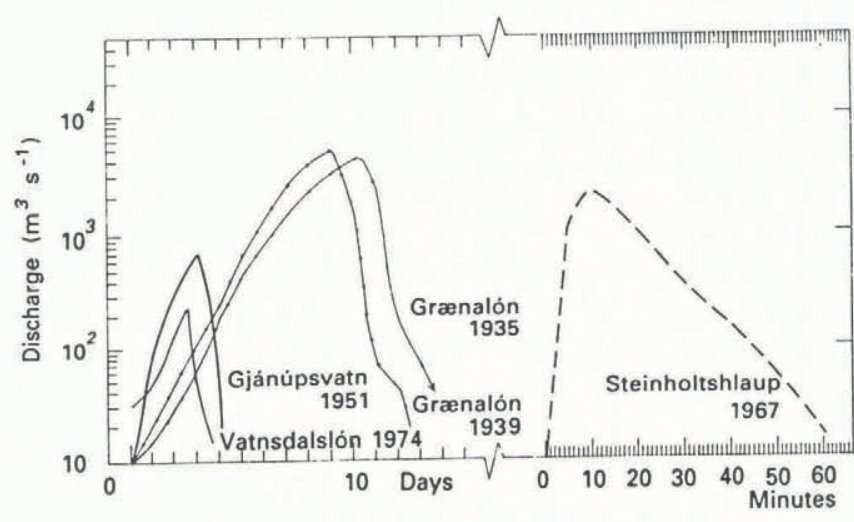

Fig. 6. Typical hydrographs of jökulhlaups from icedammed marginal lakes (Grenalón, Vatnsdalslón (Thorarinsson, 1939; Rist, 1976b); Gjánúpsvatn (Arnborg, 1955)), and a jökulhlaup caused by a rockslide (Steinsholtshlaup (Kjartansson, 1967)). 
floods from marginal lakes, however, have peaked with exceptional rapidity. In 1989 a flood from Vatnsdalslón (see Fig. 3) reached a peak of $3000 \mathrm{~m}^{3} \mathrm{~s}^{-1}$ in one day, emptying the lake (Thorarinsson, 1939). Still another type of a hydrograph is shown in Figure 6. This is a flood from Steinsholtslón (Fig. 3), caused by a rock slide into a proglacial lake. In ten minutes, the flood reached a maximum of $2000 \mathrm{~m}^{3} \mathrm{~s}^{-1}$ (Kjartansson, 1967).

The processes creating the forms of these hydrographs will be discussed further in a later section.

\section{TRIGGERING OF JÖKULHLAUPS}

Data for the conditions at the onset of jökulhlaups are available for Grímsvötn and to some extent for the icedammed lakes Grænalón and Vatnsdalslón (Thorarinsson, 1953; Björnsson, 1974, 1988). As ice flows into the Grímsvötn depression and melts, the water level rises. In general, the jökulhlaups occur when the lake has risen to a critical level, as shown in Figure 7. This has been used to predict the timing of jökulhlaups within a time interval of one year. At this lake level, however, ice overburden pressure at the ice dam is 6 to 7 bar higher than the basal hydrostatic water pressure maintained by the lake. Thus, the jökulhlaups are not triggered by simple flotation of the ice dam. Figure 8 shows the difference between the basal water pressure and the ice overburden of the ice dam at the onset of the jökulhlaup in 1986. The ice dam is some $4 \mathrm{~km}$ wide.

The static model of the ice overburden and the basal

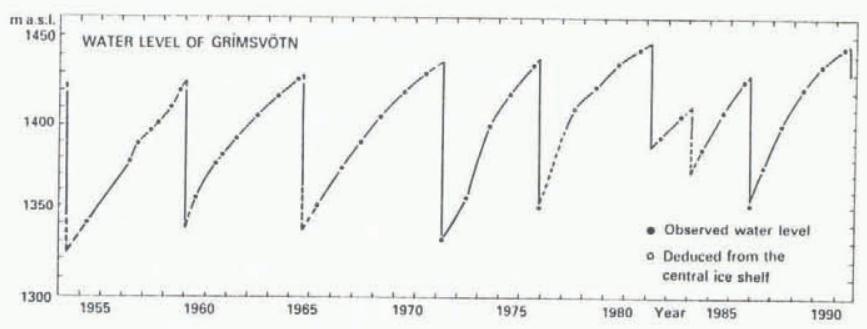

Fig. 7. Variations of water level in Grimsvötn since 1954.

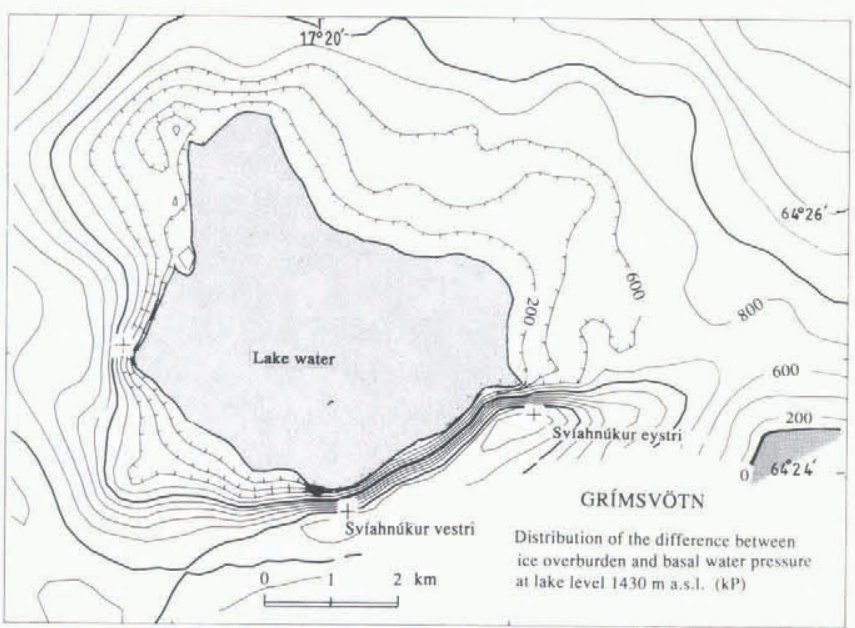

Fig. 8. A map of Grimsvötn showing the difference between ice overburden pressure and basal water pressure at the onset of the jökulhlaup in 1986 (Björnsson, 1988). water pressure does not account for weakness in the ice dam due to movements of the ice. Sudden changes in the discharge or the pressure gradients in the subglacial drainage system beneath the ice dam may cause unstable growth of the subglacial water conduits, thus producing jökulhlaups, as envisaged by Spring (unpublished work, referred to by Röthlisberger and Lang (1987), see their figure 10.17, p. 248). At the ice dam of Grímsvötn, basal meltwater could be released from vaults at spots of high geothermal activity (beneath small surface depressions). The drainage would cause enlargement of the water conduits, and, when this drainage stops, a reverse flow could start from the lake in the very same conduits, leading to an outbreak of the lake. The jökulhlaups from Grímsvötn occur at any time of the year so that sudden changes in the subglacial drainage due to surface melting do not, in general, trigger the jökulhlaups.

An increase in the lake temperature may create conditions accelerating unstable growth of conduits which drain the lake during jökulhlaups. Warming of Grímsvötn after a volcanic eruption in May of 1983 may be the reason for the outbreak of jökulhlaups at exceptionally low lake level in December 1983. Similar outbreaks at low levels in 1939 and 1941 (at 1330 and $1350 \mathrm{~m}$, respectively) may have been due to warming of the lake after an eruption in 1938 (Gudhmundsson and Björnsson, in press). However, these floods may not have drained out of the lake bottom, as jökulhlaups generally do, but through watercourses along the slopes of Grímsfjall, which were opened up by localized melting due to geothermal heat (Björnsson, 1988).

From Figure 7 we see that the critical level at which jökulhlaups start has been rising slightly since 1960 (with two exceptions early in the 1980s). At the same time the height of the ice dam east of the lake has increased. The difference between the ice overburden at the centre of the dam and the basal water pressure sustained by the lake has remained almost constant (unpublished data of the Science Institute, University of Iceland). This indicates that a jökulhlaup is triggered when the pressure barrier has been reduced to a certain level, a level which has remained the same since the 1950s (except when we suspect conditions were changed by increased geothermal activity in the early 1980s). To this discussion we can add that jökulhlaups from the marginal lakes Vatnsdalslón and Grænalón, south Vatnajökull, are triggered when the ice overburden is respectively 2 and 4 to 5 bar higher than the basal hydrostatic water pressure maintained by the lakes (see Björnsson, 1988). On these glaciers the maximum thickness of the ice dam is $200 \mathrm{~m}$ for Vatnsdalslón, and $300 \mathrm{~m}$ for Grænalón, whereas it is $550 \mathrm{~m}$ at Grímsvötn. This may indicate that the difference between the ice overburden and the basal water pressure at the onset of jökulhlaups tends to be greater when the the ice dam is thicker.

\section{SIMULATION OF DRAINAGE}

We will now consider what we can learn about the processes creating the various types of hydrographs with the aid of theoretical models of the drainage of jökulhlaups. 
Data have now been obtained which enable testing of theoretical models for simulation of jökulhlaups. The water temperature at the river outlet has been measured at the melting point throughout several of the jökulhlaups. Hence, we assume, along with Nye (1976) and Clarke (1982), that heat is transferred to the ice walls and is used for melting at a rate equal to the rate of release of potential energy by the flowing water. Clarke's (1982) modification of Nye's (1976) general model was used for the simulations. One straight cylindrical tunnel, running from the seal to the edge of the glacier was assumed. Thermal energy stored in the lake can contribute to enlargement of the tunnel. It is assumed that the evolution of the jökulhlaup is controlled by opening due to melting and creep closure of the seal at a given distance from the entrance of the tunnel. The flow-law exponent used was $\mathrm{n}=3.0$ and the flow-law coefficient $\mathrm{A}=$ $5.29 \times 10^{-15} \mathrm{kPa}^{-3} \mathrm{~s}^{-1}$; and common values were used for other physical parameters in the computations.

For Grímsvötn the geometry of the ice dam has been mapped (Björnsson, 1988) and hypsometric data constructed, as shown in Figure 2. Further, the lake temperature was measured in $1991\left(0.2^{\circ} \mathrm{C}\right.$ in the first $50 \mathrm{~m}$ below the ice shelf, $0.05^{\circ} \mathrm{C}$ for the next $50 \mathrm{~m}$ and finally increasing up to $1.5^{\circ} \mathrm{C}$ in the bottom $50 \mathrm{~m}$ ). The boundary conditions at Grímsvötn were as follows: constant lake temperature of $0.2^{\circ} \mathrm{C}$, known lake geometry and the distance from the tunnel inlet to the seal of $3.5 \mathrm{~km}$. Figures 9,10 and 11 show the results of simulation of the discharge of jökulhlaups from Grímsvötn. The model simulates with some success both the shape of the hydrograph and the peak discharge. Simulated slopes of the ascending limbs fit well to the measured ones and closure of the tunnels at the seal defines a peak of the jökulhlaup before the lake is empty. (Clarke's tunnelclosure parameter for Grímsvötn jökulhlaups is $\alpha=1$ to $1.5 \times 10^{3}$, so creep closure may stop the flood, as pointed out by Clarke.) The turnover of the computed hydrographs, however, is not as sharp as the actual ones and therefore the simulation of the descending limbs is not satisfactory. The assumption of a cylindrical tunnel apparently excludes abrupt closure of the conduit. Lowering of a flat floating ice lever onto a relatively flat rock ledge may speed up the termination of the water flow. The most accurately measured jökulhlaup so far, that of 1986 , gives the best fit for $\mathrm{n}=0.08 \mathrm{~m}^{-1 / 3} \mathrm{~s}$.

Taking into consideration that the shape of the hydrographs is reliable, whereas the peak discharges may be less accurate, the best simulations are obtained for the Manning roughness coefficients $\mathrm{n}=0.08$ to $0.09 \mathrm{~m}^{-1 / 3} \mathrm{~s}$. These values for $\mathrm{n}$ are lower than that obtained by Nye (1976) of $0.12 \mathrm{~m}^{-1 / 3} \mathrm{~s}$ for the Grímsvötn jökulhlaup of 1972. The reason is that the lake level drops more rapidly than was assumed in Nye's calculations. The more rapid drop in pressure head is compensated by lower friction in order to fit the observed hydrograph. For a jökulhlaup from Lake Hazard, Clarke (1982) obtained $0.105 \mathrm{~m}^{-1 / 3} \mathrm{~s}$, and $0.12 \mathrm{~m}^{-1 / 3} \mathrm{~s}$ for a burst from Summit Lake in 1967. Although our values for $\mathrm{n}$ are lower than these, they are two to three times higher than those observed in comparable natural streams (Chow, 1959).

Spring and Hutter (1981) modelled both the ascending and descending limbs of the Grímsvötn jökulhlaup in

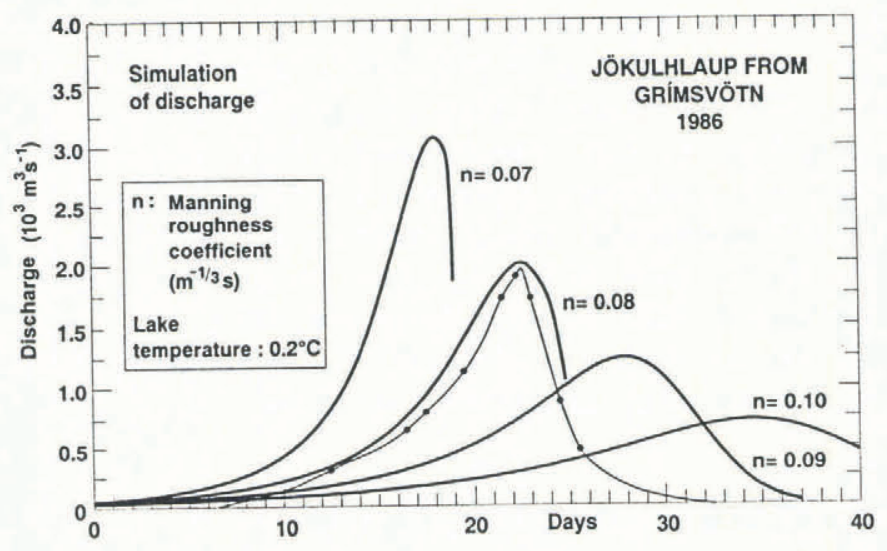

Fig. 9. Simulation of the jökulhlaup from Grimsvötn in 1986 for various values of the Manning roughness coefficient and constant lake temperature of $0.2^{\circ} \mathrm{C}$. The simulation is terminated when the lake volume is used up.

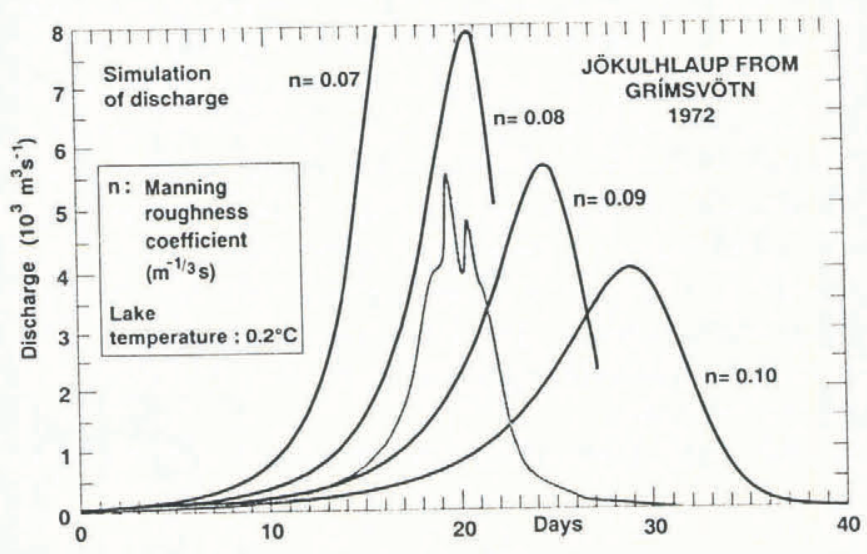

Fig. 10. Simulation of the jökulhlaup from Grimsvötn in 1972 for various values of the Manning roughness coefficient and constant lake temperature of $0.2^{\circ} \mathrm{C}$.

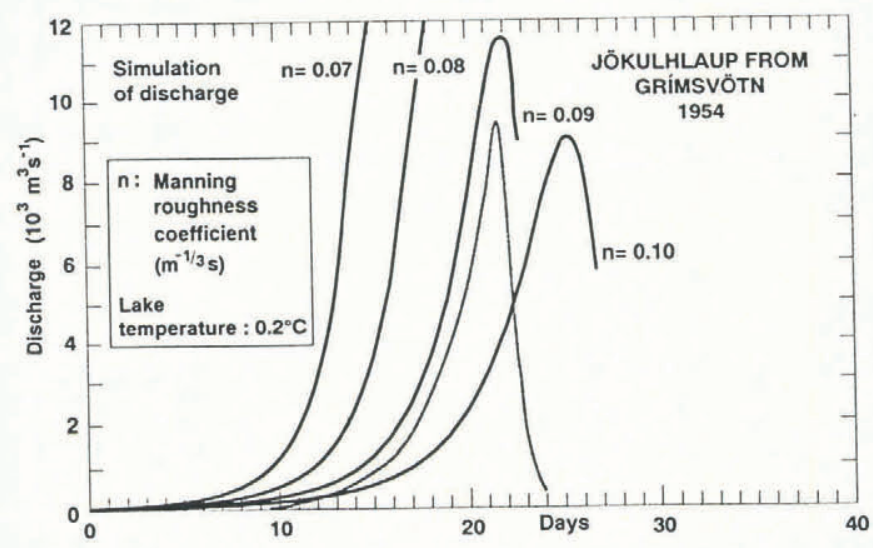

Fig. 11. Simulation of the jökulhlaup from Grimsvötn in 1954 for various values of the Manning roughness coefficient and constant lake temperature of $0.2^{\circ} \mathrm{C}$.

1972, assuming a variation with time of the water temperature at the entrance to the tunnel leading from the lake. Their best fit to the hydrograph was obtained for water temperature increasing gradually from the melting point to about $4^{\circ} \mathrm{C}$ in 19 days and then dropping to the melting point again in one day, enhancing the closure of 
the tunnel. In their model, simulation of a concave (or exponential) ascending limb presupposes transport of advective heat from the lake because their model predicts a convex (bell-shaped) ascending limb for an isothermal lake. The lake temperatures measured in 1991 do not support such assumptions (see results above). Moreover, their model of heat transfer from the flowing water to the ice walls predicts that water at temperatures of the order of 1 to $4^{\circ} \mathrm{C}$ would flow from the glacier at the peak of the jökulhlaup. However, the water has repeatedly been observed to be at the melting point. Our model, assuming instantaneous transfer of heat to the melting of the tunnel walls, describes reasonably well the Grímsvötn hydrograph of 1986. Thus, in Spring and Hutter's simulation, advected heat may have compensated for underestimated transfer of frictional heat. The transfer of frictional heat for melting ice may be more effective during jökulhlaups than is accounted for by the empirical heat transfer equation in their model. Hence, elimination of advected heat would have less effect on tunnel closure and termination of the jökulhlaup than they postulated.

Figure 12 shows simulations of the jökulhlaups in 1934 and 1938, assuming $\mathrm{n}=0.08 \mathrm{~m}^{-1 / 3} \mathrm{~s}$ (the lake geometry of 1934 (Fig. 2)), given the drop in the lake level and the distance of $2 \mathrm{~km}$ from the lake to the seal. The simulation suggests that in 1934 the lake temperature may have been higher than at present (say, $1^{\circ} \mathrm{C}$ ). The rapid ascent of the jökulhlaup in 1938, on the other hand, can only be simulated for a lake temperature of the order of $4^{\circ} \mathrm{C}$. The model, however, fails to show closure of the tunnels before the lake is empty. The shape of the ascending limb is satisfactorily simulated by Clarke's model which indicates that the heat contained in the water is used to expand the tunnel until the peak is reached and creep closure stops the jökulhlaup. The slow recession of the jökulhlaup, however, indicates that water may have escaped from the tunnel at the peak flow, spread out beneath the glacier, and collected at the river outlet in a week's time. This jökulhlaup was triggered when a volcanic eruption took place north of Grímsvötn, and meltwater of the order of 2 to $3 \mathrm{~km}^{3}$ drained down to the lake (Björnsson, 1988). A similar jökulhlaup from Grímsvötn, reaching peak discharge in 3 to 4 days was reported in 1867 (Thorarinsson, 1974; Björnsson, 1988). This flood was

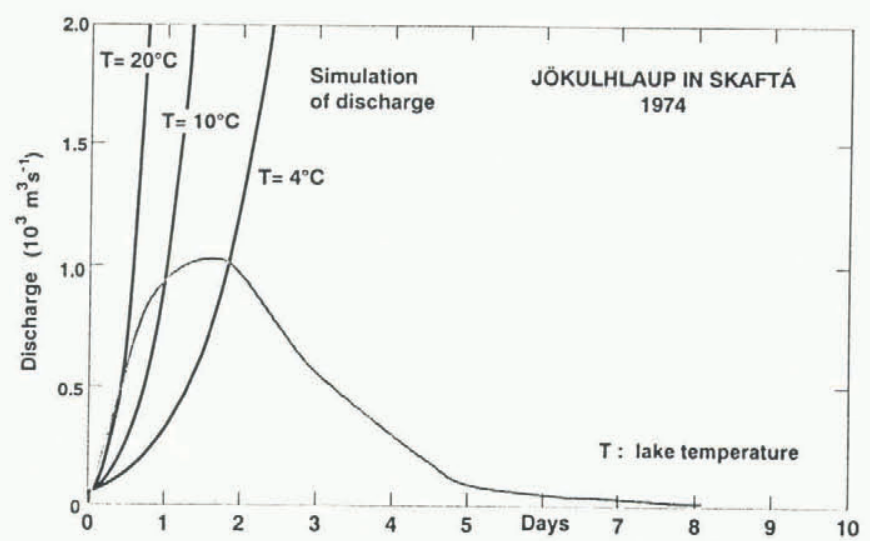

Fig. 13. Simulation of the jökulhlaups from east Skaftá cauldron in 1974 for various values of lake temperature, Manning roughness coefficient, $n=0.08 \mathrm{~m}^{-1 / 3} \mathrm{~s}$, using hypsometric data for a bowl-shaped cupola.

also accompanied by a volcanic eruption north of Grímsvötn.

Simulations fail entirely to describe the hydrographs of the jökulhlaups in Skaftá (Fig. 13). The steep rise of the jökulhlaups indicates, however, that the lake temperature is well above the melting point. The same applies to the jökulhlaup from the Katla area in 1955 (Fig. 5). The convex shape of the ascending limb suggests that heat in the water is not entirely used up in melting and expanding the conducting tunnel. However, water with temperature at the melting point drains continuously from the river outlet during the jökulhlaup, suggesting that it is not conducted in one tunnel but spreads out beneath the glacier to be slowly collected later at the river outlet (Fig. 5).

Attempts to simulate the jökulhlaups from the marginal lakes Grænalón (in 1935), Gjánúpsvatn (1951) and Vatnsdalslón (1974) fit the rise of the hydrographs reasonably well assuming constant lake temperature of about $1^{\circ} \mathrm{C}$, but they fail to model the recession (Figs. 14 and 15). The jökulhlaup from Vatnsdalslón in 1898 which reached $3000 \mathrm{~m}^{3} \mathrm{~s}^{-1}$ in one day could be simulated by drainage of lake water of about $8^{\circ} \mathrm{C}$. In 1938 a jökulhlaup from this lake reached $2000 \mathrm{~m}^{3} \mathrm{~s}^{-1}$ in 3 days,

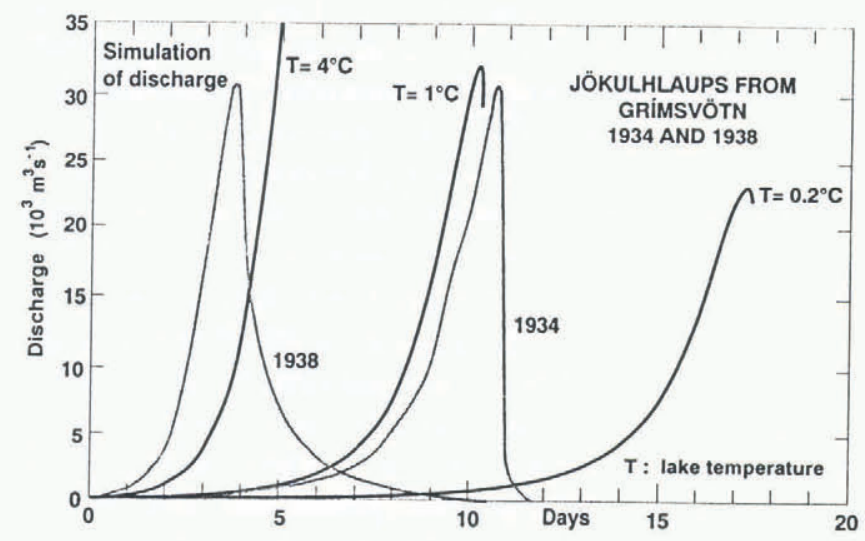

Fig. 12. Simulation of the jökulhlaups from Grimsvötn in 1934 and 1938 for various values of lake temperature. Manning roughness coefficient is $n=0.08 \mathrm{~m}^{-1 / 3} \mathrm{~s}$.

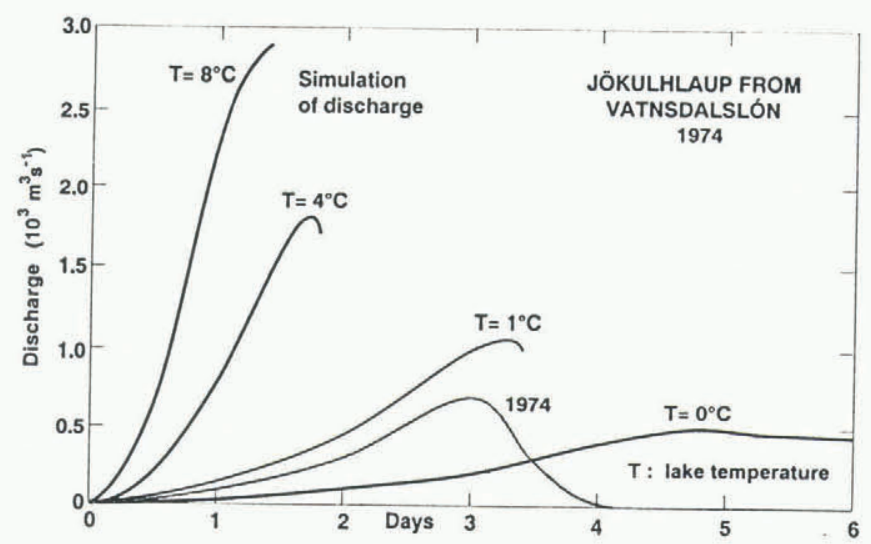

Fig. 14. Simulation of the jökulhlaups from Vatnsdalslón, 1974, for various values of lake temperature. Manning roughness coefficient, $n=0.08 \mathrm{~m}^{-1 / 3} \mathrm{~s}$. 


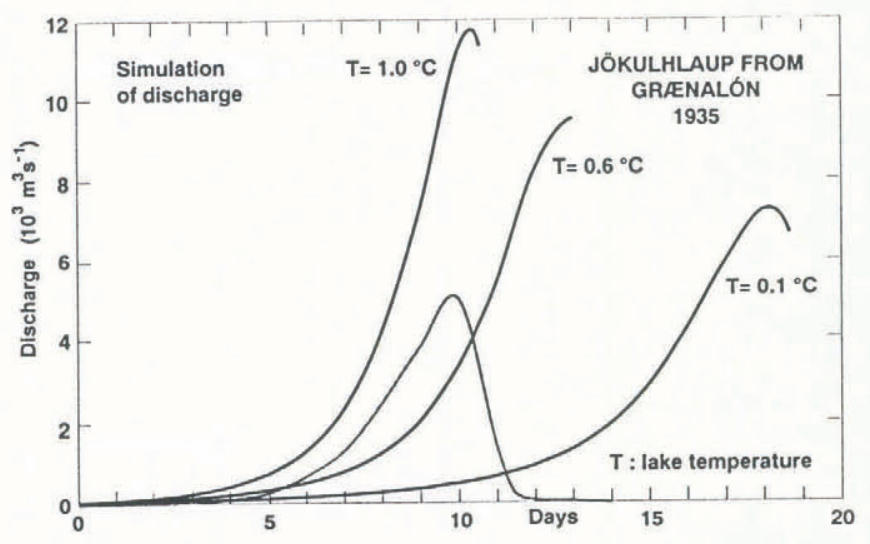

Fig. 15. Simulation of the jökulhlaups from Grenalón in 1935 for various values of lake temperature. Manning roughness coefficient, $n=0.08 \mathrm{~m}^{-1 / 3} \mathrm{~s}$. (For hypsometric data for the lake see Björnsson and Pálsson, 1989.)

which can be simulated by assuming drainage of the lake water at $4^{\circ} \mathrm{C}$.

\section{PEAK DISGHARGE AND TOTAL VOLUME OF JÖKULHLAUPS FROM GRÍMSVÖTN}

For the frequent jökulhlaups from Grímsvötn, we are able to present an empirical relationship between the peak discharge, $Q_{\max }$, and the total volume, $V_{\mathrm{t}}$, drained from the lake. Figure 16 shows this relationship for 11 jökulhlaups which fits to a power law $Q_{\max }=\mathrm{K} V_{\mathrm{t}}^{\mathrm{b}}$, where $Q_{\max }$ is measured in $\mathrm{m}^{3} \mathrm{~s}^{-1}, V_{\mathrm{t}}$ in $10^{6} \mathrm{~m}^{3}$, and $\mathrm{K}=$ $4.15 \times 10^{-3} \mathrm{~s}^{-1} \mathrm{~m}^{-2.52}$, and $\mathrm{b}=1.84$. The coefficient of determination for this relationship is $\mathrm{r}^{2}=0.97$. The total volume of water draining out of Grímsvötn in the jökulhlaups was obtained using known variations in lake level during jökulhlaups, the thickness of the floating ice cover on the lake, and the bedrock topography in the Grímsvötn area (Björnsson 1988, and unpublished work by $\mathrm{M}$. T. Gudhmundsson and H. Björnsson).

Simulation of the drainage from Grimsvötn shows that

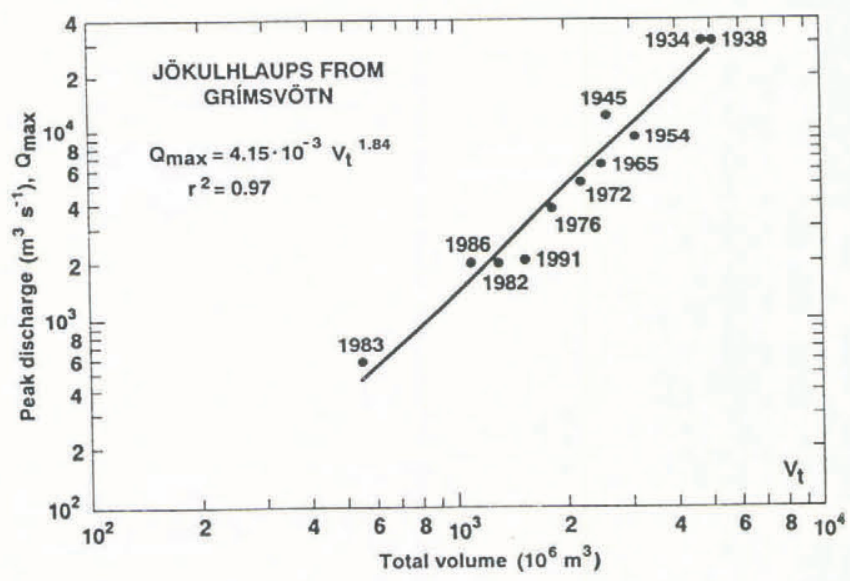

Fig. 16. The maximum discharge in jökulhlaups from Grimsvötn as a function of the total volume of water in the jökulhlaup. The accuracy of the discharge measurements is $20 \%$. the jökulhlaups considered in Figure 16 (with the exception of the 1938 jökulhlaup, and perhaps of the 1945 event as well) could have been drained from an isothermal lake close to the melting point. For jökulhlaups from lakes where there is no stored thermal energy available to melt ice, Clarke (1982) derived theoretically a power law relationship with the exponent $b=4 / 3$.

An empirical power law, similar to that proposed here, was derived by Clague and Mathews (1973) for jökulhlaups of ten marginal ice-dammed lakes from various parts of the world, ranging in volume from $10^{6}$ to $10^{9} \mathrm{~m}^{3}$. They obtained $\mathrm{K}=75 \mathrm{~s}^{-1} \mathrm{~m}^{-0.99}$ and $\mathrm{b}=0.67$ where $V_{\mathrm{t}}$ was given in $10^{6} \mathrm{~m}^{3}$. For jökulhlaups where thermal energy from the lake is the dominant contribution to melting of the tunnel, Clarke (1982) derived theoretically the exponent $\mathrm{b}=4 / 5$.

\section{CONGLUSIONS}

From the data and models presented, the following can be concluded for jökulhlaups from lakes at subglacial geothermal areas and from marginal ice-dammed lakes in Iceland:

1. In general, jökulhlaups occur when a lake has risen to a critical level but before the hydrostatic water pressure maintained by the lake is equal to the ice overburden pressure of the ice dam. The difference between ice overburden and the water pressure at the onset of a jökulhlaup tends to be greater the thicker the ice dam is.

2. Clarke's (1982) modification of Nye's (1976) general model of discharge of jökulhlaups yields moderately good simulations for jökulhlaups from Grímsvötn. In general, the simulated slopes of the ascending limbs can be fitted to the measured ones, and closure of the tunnels at the seal defines a peak of the jökulhlaup before the lake is empty. The turnover of the computed hydrographs, however, is not as sharp as the actual ones, and therefore the simulation of the descending limbs are not satisfactory. This presumably arises because, in the model, the tunnel is assumed to be cylindrical. The best fit is obtained for the Manning roughness coefficient $\mathrm{n}=0.08$ to $0.09 \mathrm{~m}^{-1 / 3} \mathrm{~s}$. These values for the Manning roughness coefficient are lower than that obtained by Nye (1976) of $0.12 \mathrm{~m}^{-1 / 3} \mathrm{~s}$ for the Grímsvötn jökulhlaup of 1972.

The actual heat transfer by flowing water during jökulhlaups is more effective than accounted for by Spring and Hutter's (1981) model for simulation of drainage (as pointed out by Nye (1976)). The empirical heat transfer equation may be wrong at the high Reynolds numbers in the jökulhlaups. On the other hand, melting of ice may not be restricted to the walls, because ice needles, eroded by debris and sand from the walls, mix with the water.

3. The typical hydrographs of jökulhlaups from Grímsvötn rise approximately exponentially; after reaching the peak, the discharge falls more rapidly. The duration of larger floods tends to be shorter than that of smaller ones. In all cases the jökulhlaups end before Grímsvötn is empty. Simulations suggest that these jökulhlaups drain from a lake whose temperature is close to the melting point $\left(0.2^{\circ} \mathrm{C}\right)$. On the other hand, the rapid ascent of the jökulhlaup of 1938, which was 
triggered by a volcanic eruption, can only be simulated for a lake temperature of the order of $4^{\circ} \mathrm{C}$. In this case, however, the model fails to show closure of the tunnels before the lake is empty.

4. The typical hydrograph for jökulhlaups from the eastern Skaftá cauldron rises rapidly and recedes slowly. The form has in that respect a reversed asymmetry of the typical Grímsvötn hydrograph. Simulations fail entirely to describe the hydrographs. The lake temperature must be well above the melting point $\left(10\right.$ to $\left.20^{\circ} \mathrm{C}\right)$; but the thermal energy of the water is not entirely used up for melting and expanding the conducting tunnel, because water is spread out beneath the glacier and, later, slowly collected back to the river outlet, where its temperature is measured at the melting point. This applies also to the jökulhlaup from the Katla area in 1955.

5. Hydrographs for jökulhlaups from marginal lakes have a shape similar to the typical Grímsvötn jökulhlaup. The ascent of the hydrographs can be simulated for constant lake temperature of about $1^{\circ} \mathrm{C}$, but modelling fails to describe the recession. Some floods from marginal lakes which reached their peaks exceptionally rapidly (in one day, emptying the lake) could be simulated by assuming drainage of lake water at 4 to $8^{\circ} \mathrm{C}$.

6. For jökulhlaups from Grímsvötn, the peak discharge, $Q_{\max }$, and the total volume, $V_{\mathrm{t}}$, drained from the lake fit to a power law $Q_{\max }=\mathrm{K} V_{\mathrm{t}}^{\mathrm{b}}$ where $Q_{\max }$ is measured in $\mathrm{m}^{3} \mathrm{~s}^{-1}, V_{\mathrm{t}}$ in $10^{6} \mathrm{~m}^{3}$, and $\mathrm{K}=$ $4.15 \times 10^{-3} \mathrm{~s}^{-1} \mathrm{~m}^{-2.52}$, and $\mathrm{b}=1.84$.

\section{ACKNOWLEDGEMENTS}

I am grateful to T. Jóhannesson for writing the numerical program of Clarke's model in collaboration with me in 1982-83 and F. Pálsson for assistance running the programs. M. T. Gudhmundsson worked with the author on estimating the hypsometric data for Grímsvötn. The Icelandic Road Authority is acknowledged for continuing support of the studies of jökulhlaups. Much of the data from Grímsvötn have been collected in expeditions of the Iceland Glaciological Society. Many of the figures were drawn at the National Power Company. The work has been supported by the Research Fund of the University of Iceland and the Icelandic Science Fund. I am indebted to my wife Thóra Ellen Thórhallsdóttir for proof-reading and assistance, and to M. Karlsson who read the final manuscript and made several corrections to the English text.

\section{REFERENGES}

Arnborg, L. 1955. Hydrology of the glacial river Austurfljót. Geogr. Ann., 37(3-4), 185-201.

Björnsson, H. 1974. Explanation of jökulhlaups from Grímsvötn, Vatnajökull, Iceland. Jökull, 24, 1-26.

Björnsson, H. 1975. Subglacial water reservoirs, jökulhlaups and volcanic eruptions. Fökull, 25, 1-14.

Björnsson, H. 1976. Marginal and supraglacial lakes in Iceland. Jökull, 26, 40-51.

Björnsson, H. 1977. The cause of jökulhlaups in the Skaftá river, Vatnajökull. Jökull, 27, 71-78.
Björnsson, H. 1988. Hydrology of ice caps in volcanic regions. Visindafélag Ísl. Rit 45.

Björnsson, H. and F. Pálsson. 1989. Rúmmál Grænalóns og breytingar á stærdh og tídhni jökulhlaupa. Jökull, 39, 90-95.

Björnsson, H. and P. Einarsson. 1991. Volcanoes beneath Vatnajökull, Iceland: evidence from radio echosounding, earthquakes and jökulhlaups. Jökull, 40, 1990, 147-168.

Chow, V.T. 1959. Open-channel hydraulics. New York, McGraw Hill.

Clague, J.J., and W.H. Mathews. 1973. The magnitude of jökulhlaups. F. Glaciol., 12(66), 501-504.

Clarke, G.K.C. 1982. Glacier outburst flood from "Hazard Lake", Yukon Territory, and the problem of flood magnitude prediction. 7. Glaciol., 28(98), 3-21.

Gudhmundsson, M.T. 1989. The Grímsvötn caldera, Vatnajökull: subglacial topography and structure of caldera infill. Jökull, 39, 1-20.

Gudhmundsson, M.T. and H. Björnsson. In press. Volcanic eruptions in Grímsvötn, Vatnajökull, Iceland, 1934-1990. Jökull.

Jónsson, J. 1982. Notes on the Katla volcanoglacial debris flows. Jökull, 32, 61-68.

Kjartansson, G. 1951. The eruption of Hekla 1947-48. II. 4. Water flood and mud flows. Reykjavík, Vísindafélag Íslendinga.

Kjartansson, G. 1967. The Steinsholtshlaup, centralsouth Iceland on January 15th, 1967. Jökull, 17, 249 262.

Kristinsson, B., S. Zophóníasson, S. Pálsson and H. Kristmannsdóttir. 1986. Hlaup á Skeidharársandi 1986. Reykjavík, National Energy Authority.

Maizels, J. 1989. Sedimentology and paleohydrology of Holocene flood deposits in front of a jökulhlaup glacier, south Iceland. In Beven, K. and P. Carling, eds. Floods. Hydrological, sedimentological and geomorphological implications. New York, John Wiley and Sons, 239-252.

Maizels, J. 1991. The origin and evolution of Holocene sandur deposits in areas of jökulhlaup drainage, Iceland. In Maizels, J. and C. Caseldine, eds. Environmental change in Iceland: past and present. Dordrecht, Kluwer Academic Publishers, 267-279.

Nye, J.F. 1976. Water flow in glaciers: jökulhlaups, tunnels and veins. 7. Glaciol., 17(76), 181-207.

Rist, S. 1955. Skeidharárhlaup. Jökull, 5(30-36).

Rist, S. 1967. Jökulhlaups from the ice cover of Mýrdalsjökull on June 25, 1955 and January 20, 1956. Jökull, 17, 243-248.

Rist, S. 1973. Jökulhlaupaannáll 1971, 1972 og 1973. Jökull, 23, 55-60.

Rist, S. 1976a. Grímsvatnahlaupidh 1976. Jökull, 26, 8090.

Rist, S. 1976b. Jökulhlaupaannáll 1974, 1975 og 1976. Jökull, 26, 75-79.

Rist, S. 1981. Jökulhlaupaannáll 1977, 1978 og 1980. Jökull, 31, 31-35.

Rist, S. 1984. Jökulhlaupaannáll 1981, 1982 og 1983. Jökull, 34, 165-179.

Röthlisberger, H. and H. Lang. 1987. Glacial hydrology. In Gurnell, A. M. and M.J. Clarke, eds. Glacio-fluvial sediment transfer; an alpine perspective. Chichester, etc. John Wiley and Sons, 207-284. 
Spring, U. and K. Hutter. 1981. Numerical studies of jökulhlaups. Cold Reg. Sci. Technol., 4(3), 221-244.

Tómasson, H. 1973. Hamfarahlaup í Jökulsá á Fjöllum. Náttúrufredhingurinn, 43(1-2), 12-34.

Tómasson, H. 1991. Glaciofluvial sediment transport and erosion. In Gjessing, Y., J. O. Hagen, K. A. Hassel, K. Sand and B. Wold, eds. Arctic hydrology. Present and future tasks. Hydrology of Svalbard - hydrological problems in cold climate. Seminar Longyearbyen, Svalbard, 14-17 September 1990. Oslo, Norwegian National Commmittee for Hydrology, 27-36. (Report 23.)

Thorarinsson, S. 1939. The ice dammed lakes of Iceland with particular reference to their values as indicators of glacier oscillations. Geogr. Ann., 21(3-4), 216-242.

Thorarinsson, S. 1953. Some new aspects of the
Grímsvötn problem. J. Glaciol., 2(14), 267-275.

Thorarinsson, S. 1957. The jökulhlaup from the Katla area in 1955 compared with other jökulhlaups in Iceland. Jökull, 7, 21-25.

Thorarinsson, S. 1958. The Öræfajökull eruption of 1362. Acta Nat. Isl., 2(2).

Thorarinsson, S. 1965. Changes of the water-firn level in the Grímsvötn caldera 1954-1965. Jökull, 15, 109-119.

Thorarinsson, S. 1974. Vötnin strídh. Reykjavík, Bókaútgáfa Menningarsjóds.

Thorarinsson, S. 1975. Katla og annáll Kötlugosa. Árbók Ferdhafélags Íslands, 125-149.

The accuracy of references in the text and this list is the responsibility of the author/s, to whom queries should be addressed. 